\title{
Value Analysis of Hot Spots of Society in Ideological and Political Education in Higher Schools
}

\author{
Qian Zan \\ Xi'an Medical College, Xi'an 710021, Shanxi, China
}

Keywords: Hot spots of society; Ideological and political education in higher schools; Value analysis

\begin{abstract}
In the information era, hot spots of society begin to affect people's daily work and life, and to some extent, people's ideology is also constrained by hot spots of society. The influence exerted by hot spots of society will be bound to enter the ideological and political education classroom in higher schools, thus directly determining the value orientation of college students. Based on this, this paper focuses on the value analysis of hot spots of society in the ideological and political education in higher schools.
\end{abstract}

\section{Introduction}

With the rapid development of social economy and the rapid progress of science and technology, China's education resources have also presented diversification, the educational methods have been improved, and various higher schools have achieved favorable results in the cultivation of modern talents. In particular, in the context of gradual deepening of educational reform, the educational level of various higher schools in China has also been greatly improved. However, due to the adverse effects caused by the market economy, most of the higher schools and college students only focus on improving the technical level and absorbing professional knowledge, but did not pay enough attention to the ideological and political education. For higher schools, the existing ideological and political education should be strengthened, as based on this, this paper focuses on the value analysis of hot spots of society in ideological and political education in higher schools.

\section{The concept and characteristics of hot spots of society}

Hot spots of society mainly refer to the problems and phenomena that raise high awareness in all the social fields within specific time period, have strong appeal and arouse high social response. Hot spots of society involve a wide range of issues, including not only breaking news of the country, but also small problems in daily life. However, as long as a problem or an incident has caused great concern in society in a specific period of time, and exerted big impact in society, it can be defined as the hot spot of society.

The major reason why hot spots of society can attract people's high attention is that they have obvious characteristics, those are timeliness, abruptness and complexity. Timeliness refers to that in a certain period of time, the emergence of some hot spot of society has attracted people's attention, however, with the passage of time, the attention paid to it by the society will be less and less. Abruptness mainly refers to that hot spots of society are often abruptly announced publicly without any signs. Complexity mainly refers to that the relations between hot spots of society are complicated, and it is relatively difficult to deal with the issues. For example, "college entrance examination system reform", "medical insurance", "against terrorist attacks" and other social issues reported by the major media all reflect some complexity, and are difficult to be dealt with. 


\section{Value embodiment of hot spots of society in ideological and political education in higher schools}

\subsection{The ideological trend affecting college students}

In general, in order to ensure the improvement of the quality of ideological education, ideological and political staff in higher schools must grasp the ideological trend of contemporary college students and timely control the ideological trend, so as to respond effectively to it in case of emergencies, and to make scientific instruction for the ideological and political work. As teacher lecturers can play a guiding role in the ideological and political education, they are required to possess high political caliber, lofty moral feelings and high sense of duty, in particular, the ideological and political teachers should play a better guiding role on the students' ideological activities, thus promoting the students to form good moral qualities [1]. It can be seen from plenty of teaching practices that, if teacher lecturers can deal with problems encountered in the process of teaching according to the students' thinking patterns, the teacher-student relationship may be closer, in addition, the students' learning initiative can be improved, and the teaching efficiency of higher schools can be significantly improved. From the overall perspective, the ideological and political education occupies a high proportion in university education, therefore, teacher lecturers must pay more attention to students' ideological behaviors in education, communicate more with the students, and make the students realize that all that the teachers do is for their personal development. College students attach great importance to hot spots of society, as these issues will exert certain impact on thoughts and actions of them. Hence, teacher lecturers should carry out teaching aiming at individual differences, and make concrete analysis of concrete problems, so as to greatly enhance the teaching effect. Teacher lecturers can use related websites or forums to grasp the opinions of contemporary college students on hot spots of society at current stage and the degree of emphasis of them, besides, through the opinions, teacher lecturers can learn the development trend of thoughts and actions of college students, based on this, they can correctly guide contemporary college students' thoughts and implement ideological and political education.

\subsection{Conducive to improving students' ability to solve problems}

Practice is the sole criterion for testing truth, and theory can guide practice. The previous ideological and political education attached great importance to the teaching of theories, but less attention was paid to practice research. The effectiveness of ideological and political theories can only be tested through practice. The inclusion of hot spots of society into the ideological and political education can not only mobilize the initiative of students, but also help improve students' ability to solve problems, so that students will pay attention to the society, and understand livelihood issues. The main reason why large number of hot spots of society can attract people's high attention is that they are not only closely related to people's lives, but also closely bound up with the development and progress of society. For example, the current issue of " rise of housing price" has always been a social hot spot, as it not only has certain relationship with people's production and living, but also involves the transformation of social economy. Integrating effective hot spots of society into ideological and political education can promote students to pay attention to social reality and improve their ability to think about and solve problems.

\subsection{Conducive to improving students' critical thinking ability}

Since the ideological and political education in higher schools runs counter to the contents students are concerned about, the participation of students is reduced, and the ideological and political education was not given high affirmation. Higher schools should stimulate the enthusiasms of students in participating in discussing hot spots through the application of information technology, thus achieving the purpose of make students learn the content of ideological and political education. For example, higher schools have set up ideological and political network exchange platform, but a special column for discussion on hot spots should be set up in this 
platform, so that students can discuss hot spots and express their opinions, which is conducive to improving their critical thinking ability [2].

\subsection{Conducive to improving students' learning initiative}

University is the main place for training socialism successors. Ideological and political education plays an irreplaceable role in the educational patterns of universities, and directly determines the correct establishment of the world outlook and values of college students. Higher school teachers in ideological and political courses should adhere to the people-oriented principle in guiding the ideological and political education, promote the students to pay attention to social reality, improve students' learning interest, integrate social hot spots into the ideological and political education, and potentially guide thoughts and actions of students[3]. For example, higher schools should organize students to carry out debate competitions or lectures associated with social hot spots, thus improving students' enthusiasm in participating in the ideological and political learning activities, and making students form correct three outlooks through discussion on hot spots.

\section{Conclusions}

To sum up, although higher schools have set up ideological and political education courses, they did not obtain the desired teaching effect. Besides, the education failed to give full play to its practical effect. Based on this, this paper integrates social hot spots into the ideological and political education in higher schools, which is the need of social development, and can not only improve the enlightenment of ideological and political education, but also improve students' ability to solve problems.

\section{Acknowledgement}

In this paper, the research was sponsored by the Foundation project of philosophy and social science 2015R037 in Shaanxi province: Studying under the perspective of Silk Road to the Belt and Road of rural doctors team development in Shaanxi province.

\section{References}

[1] Chen Hongying, Yu Yanhua. Investigation on the value of social hot sopts in ideological and political education in higher schools [J]. Management \& Technology of SME (midmonth edition), 2015 (12): 168.

[2] Nan Mengfei. Investigation on the value of social hot sopts in ideological and political education in higher schools [J]. Western China Quality Education, 2017, 3 (14): 37.

[3] Zhang Longhui. Brief discussion on the application value of social hot sopts in ideological and political education in higher schools. Course Education Research, 2015 (12). 